\begin{tabular}{|l|l|l||}
\hline \multicolumn{2}{|c|}{ PublisherInfo } \\
\hline \hline PublisherName & $:$ & BioMed Central \\
\hline \hline PublisherLocation & $:$ & London \\
\hline \hline PublisherImprintName & $:$ & BioMed Central \\
\hline \hline
\end{tabular}

\title{
Isolating the cow genome
}

\begin{tabular}{|l|l|l||}
\hline \multicolumn{2}{|c|}{ ArticleInfo } \\
\hline \hline ArticleID & $:$ & 3960 \\
\hline \hline ArticleDOI & $:$ & $10.1186 /$ gb-spotlight-20010118-02 \\
\hline \hline ArticleCitationID & $:$ & spotlight-20010118-02 \\
\hline \hline ArticleSequenceNumber & $:$ & 31 \\
\hline \hline ArticleCategory & $:$ & Research news \\
\hline ArticleFirstPage & $:$ & 1 \\
\hline \hline ArticleLastPage & $:$ & 2 \\
\hline \hline & $:$ & RegistrationDate : 2001-01-18 \\
ArticleHistory & $:$ & OnlineDate \\
\hline \hline ArticleCopyright & $:$ & BioMed Central Ltd2001-01-18 \\
\hline \hline ArticleGrants & $:$ & \\
\hline \hline ArticleContext & $:$ & 130592211 \\
\hline \hline
\end{tabular}




\section{Jonathan B Weitzman}

Email: jonathanweitzman@hotmail.com

Inbreeding is thought to cause reduced genetic variation and diminished viability. In the January 18 Nature, Visscher et al. studied the genome of a viable herd of cows, Chillingham cattle (Bos taurus), that have lived as an isolated inbred herd for over 300 years in the north of England (Nature 2001, 409:303). Visscher et al. analyzed 13 of the Chillingham animals (the breed totals just 49 animals) and scored for 25 polymorphic microsatellite markers. They report that the herd is remarkably homozygous, with only one marker displaying heterozygosity. The authors suggest that any deleterious alleles have been purged from this population and that the Chillingham herd may make a useful contribution to bovine genome studies.

\section{References}

1. Conservation genetics.

2. Nature, [http://www.nature.com/nature/]

3. The Wild White Cattle of Chillingham, [http://www.whitepark.org.uk/chillingham.htm]

4. Bovine Genome Database, [http://bos.cvm.tamu.edu/bovgbase.html] 